\title{
Ice thickness measurements of Guliya ice cap, western Kunlun Mountains (Tibetan Plateau), China
}

\author{
STANISLAV KUTUZOV, ${ }^{1,2}$ [1 LONNIE G. THOMPSON,${ }^{1}$ IVAN LAVRENTIEV, ${ }^{2}$ \\ LIDE TIAN ${ }^{3}$ \\ ${ }^{1}$ Byrd Polar and Climate Research Center, The Ohio State University, Columbus, OH, USA \\ ${ }^{2}$ Institute of Geography Russian Academy of Sciences, Moscow, Russia \\ ${ }^{3}$ Key Laboratory of Tibetan Environment Changes and Land Surface Processes, Institute of Tibetan Plateau Research, \\ Chinese Academy of Sciences, Beijing, China \\ Correspondence: Stanislav Kutuzov <kutuzov@igras.ru>
}

\begin{abstract}
Despite their high value and importance for various glaciological applications, detailed ice thickness measurements of alpine glaciers are still very limited. Knowledge of bedrock topography is essential for paleoglaciological studies. The Guliya ice cap located on the Tibetan Plateau is one of the highest and largest ice caps in mid-low latitude regions. A detailed ground-penetrating radar (GPR) survey was conducted on the Guliya ice cap in 2015 using 20 and $40 \mathrm{MHz}$ frequency antennas. An empirical Bayesian kriging method was used for ice thickness interpolation and uncertainty assessment. GPR measurements revealed complex basal topography of the Guliya glacier with a maximum thickness of $371.12 \pm 13 \mathrm{~m}$. The internal reflections caused by changes in the dielectric properties were registered on the $40 \mathrm{MHz}$ radargrams at the summit and were attributed to density variations. As a result of this fieldwork, one of the largest ice thickness datasets in High Mountain Asia was obtained. Guliya glacier elevation changes were assessed by differencing digital elevation models. The glacier gained mass from 2000 to 2015 with an average rate of $0.270 \pm 0.11 \mathrm{~m}$ w.e. $\mathrm{a}^{-1}$ at the summit and $0.279 \pm 0.11 \mathrm{~m}$ w.e. $\mathrm{a}^{-1}$ at the lower elevations.
\end{abstract}

Keywords: glacier geophysics, ground-penetrating radar, ice thickness measurements

\section{INTRODUCTION}

Glacier ice thickness distribution and bedrock topography are important basic parameters for a number of applications, such as ice volume estimation (e.g. Navarro and others, 2014), modeling of future glacier dynamics (Zekollari and others, 2014), hydrological projections (Gabbi and others, 2012), studies of glacier-related hazards and glacial lake formation (Vincent and others, 2012), and ice core studies (Eisen and others, 2003) among many others. Despite their importance, ice thickness measurements are limited, mainly due to logistical difficulties. This is especially true for the most remote and high-altitude glaciers. A recent compilation of available ice thickness data shows that detailed glacier-wide thickness measurements are available for only 550 glaciers (Gärtner-Roer and others, 2014, 2016).

A number of attempts have been made to model glacier ice thickness based on surface topography, mass balance, ice flow velocities and theoretical assumptions. Recent model comparisons show discrepancies, especially for ice caps, and indicate a high demand for detailed glacier ice thickness data against which the models can be calibrated and validated (Farinotti and others, 2017).

Ground-penetrating radar (GPR) is a geophysical method widely used for various glaciological applications (Navarro and Eisen, 2009). It is based on registering electromagnetic wave reflections from internal glacier features and bedrock. Two primary research goals in glaciological GPR studies are measurements of ice thickness and evaluation of glacier internal structure (Dowdeswell and Evans, 2004). Besides its scientific and practical importance, knowledge of these parameters is essential for paleoglaciological studies and ice flow modeling. The value of including GPR in alpine glacier coring investigations has been demonstrated by studies in the Swiss Alps (Eisen and others, 2003), Caucasus (Mikhalenko and others, 2015) and most recently on Kilimanjaro (Bohleber and others, 2017).

Bedrock topography information and englacial layering are crucial for selecting deep ice core drilling sites as well as interpretation of ice core records (Konrad and others, 2013). Data on bedrock topography and internal structure of the Colle Gnifetti glacier in the Swiss Alps enabled 3-D internal age distribution modeling (Eisen and others, 2003; Konrad and others, 2013). The internal reflections are considered to be from layers initially formed on the glacier surface. These isochronal layers can be used to connect separate ice core records, estimate accumulation distribution, and calibrate age/depth relationships (Pälli and others, 2002; Konrad and others, 2013; Sold and others, 2015; Bohleber and others, 2017). The high mountain drilling sites can be very difficult to model as the variations in ice depth and snow accumulation can reach orders of magnitude within very short distances. Reliable modeling of the age/depth relationship and its distribution require accurate ice thickness and bedrock topography data.

The Tibetan Plateau, often referred to as the Third Pole, and its surrounding mountains accommodate the largest number of glaciers outside the Polar Regions, with a total glacial area of $100000 \mathrm{~km}^{2}$ (Yao and others, 2012a). Its geographical location, size, and elevation define the major impact of the Third Pole on large scale atmospheric circulation patterns (Yao and others, 2012a). Considerable effort has been applied toward glacier monitoring in Central Asia and 
on the Tibetan Plateau in particular (Bolch and others, 2012; Yao and others, 2012b; Sorg and others, 2012; Neckel and others, 2014; Yi and Sun, 2014; Farinotti and others, 2015; Ye and others, 2017). However, glacier wide data on ice thickness are still very limited due to remote locations and extremely high elevations. Ice thickness datasets exist for selected glaciers in the Tien Shan, Urumqi Glacier No. 1 (Wang and others, 2014), the central Tibetan Plateau, Qiangtang glacier (Zhu and others, 2014), Muz Taw glacier in the Sawir Mountains (Baojuan and others, 2015) and the southern Tibetan Plateau (Tian and others, 2014).

The Guliya ice cap in the western Kunlun Mountains is the highest and largest (total area of $376 \mathrm{~km}^{2}$, flat-top area of $132 \mathrm{~km}^{2}$ ) ice cap in the mid to low latitudes (Yao and others, 1992). It is characterized by extremely cold, polarlike conditions (Thompson and others, 1995). A deep drilling program conducted in the summer of 1992 resulted in the longest ice core climate record outside the Polar Regions ( 130000 years), and showed that even older ice is preserved in the deepest layers of the glacier (Thompson and others, 1997). Prior to the 1992 drilling program, field studies were conducted in 1990 and 1991 which included surface accumulation measurements, shallow core and snow pit sampling and surface ice flow velocity measurements. Ice thickness was measured around the ice cap at several discrete points with a short-pulse radar operating using a central frequency of $10 \mathrm{MHz}$. Thompson and others $(1995,1997)$ and Yao and others (1992) provided detailed descriptions of the field measurements and laboratory methods used in climatic and environmental studies of the Guliya ice cap.
In this paper, we present detailed ice thickness measurements conducted on the Guliya ice cap using GPR during a drilling campaign in 2015. The total length of GPR profiles on the Guliya ice cap was $\sim 80 \mathrm{~km}$, making it one of the largest ice thickness datasets in Central Asia. The results of the GPR measurements were compared with the borehole depth and ice core stratigraphy. We assessed surface elevation changes of the ice cap and neighboring glaciers from 2000 to 2015 .

\section{DATA COLLECTION AND PROCESSING}

The Guliya ice cap is located on the western edge of the Tibetan Plateau in far western Kunlun Shan, China. It spans an elevation range of $1000 \mathrm{~m}$, with its summit at $6650 \mathrm{~m}$ a.s.l. Most of the surface consists of flat areas with an average slope of $<3-5^{\circ}$; however the slope increases toward the summit and the north-east where a large outlet glacier is located.

In September and October of 2015 a geophysical survey was conducted in two areas covering a total area of $\sim 18 \mathrm{~km}^{2}$ located on the Guliya Plateau (GP) and the Guliya Summit (GS) near the ice core drilling sites (Fig. 1). The main dataset, consisting of $\sim 70 \mathrm{~km}$ of GPR profiles, was obtained from the GP (5900-6200 m a.s.I.) with denser profiling conducted in the vicinity of the drilling site $\left(35^{\circ}\right.$ $\left.13^{\prime} 58.8^{\prime \prime} \mathrm{N}, 81^{\circ} 28^{\prime} 5.729^{\prime \prime} \mathrm{E}\right)$. Profiles around the GS drilling site $\left(35^{\circ} 17^{\prime} 22.474^{\prime \prime} \mathrm{N}, 81^{\circ} 29^{\prime} 43.979^{\prime \prime} \mathrm{E}\right)$ cover the elevation range of $6590-6650 \mathrm{~m}$ a.s.l.

For ice thickness measurements we used commercial high-performance GPR manufactured by Geophysical

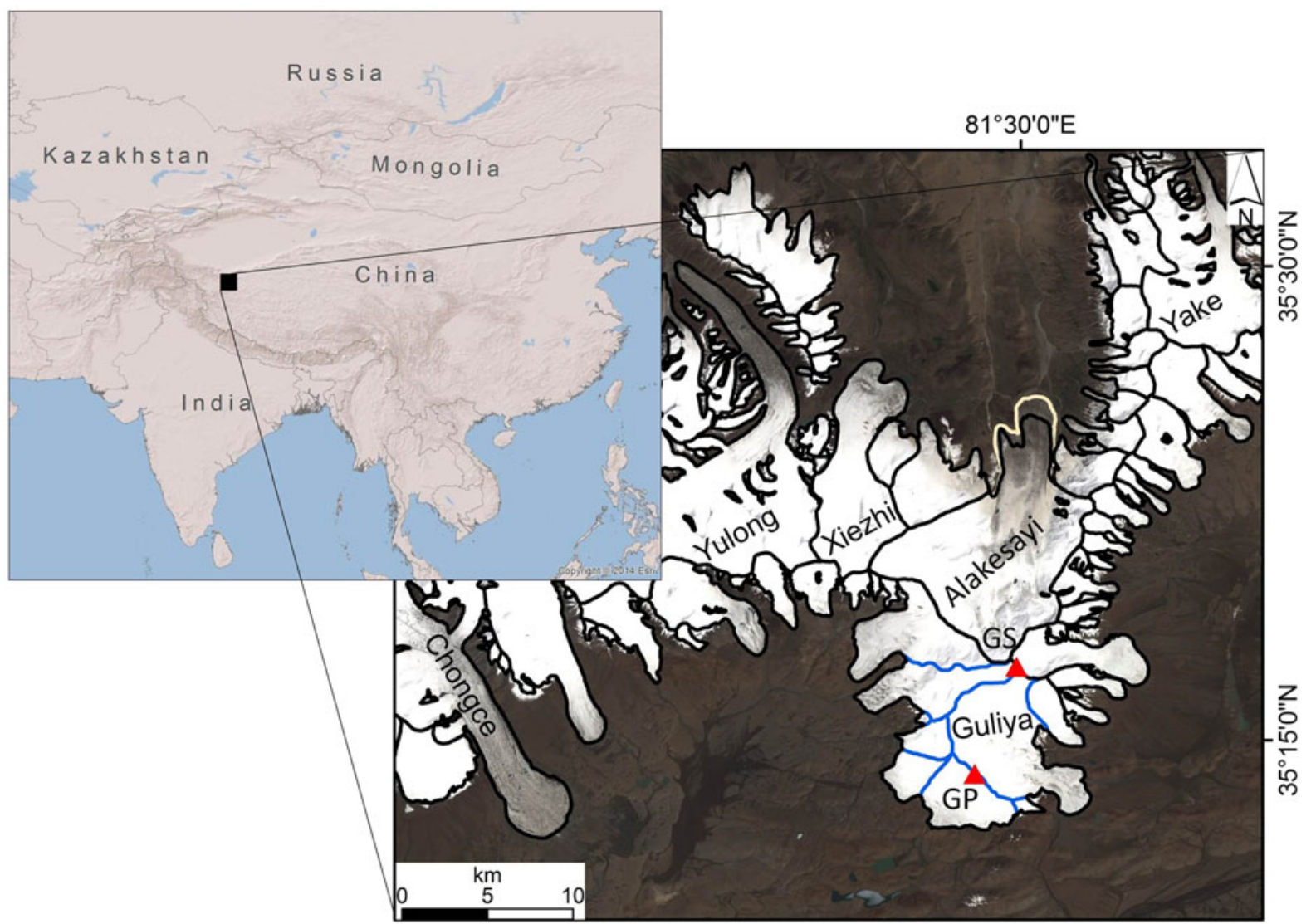

Fig. 1. Location of the Guliya ice cap and ice core drilling sites (red triangles). The image of the icefield, of which Guliya is a part, is a Sentinel$2 \mathrm{~A}$ image from 08 August 2017. The RGl 6.0 glacier outlines (RGI Consortium, 2017) are shown in black, ice drainage basins of the Guliya ice cap are shown in blue. Note the Alakesayi glacier advance, outlined in white, in 2015-2017. Map created using ArcGIS ${ }^{2}$ software by Esri. 
Survey Systems Incorporated (GSSI). Such a radar is widely used in glaciological applications, both in the polar and in alpine regions (e.g. Shean and Marchant, 2010; Singh and others, 2012; Kehrl and others, 2014). The 3200 Multiple Low Frequency Antennas with a center frequency of $\sim 20$ and $40 \mathrm{MHz}$ were used for the survey at the GP and GS sites, respectively. The antenna is composed of two fully extended $(240 \mathrm{~cm}$ for $20 \mathrm{MHz}$ and $120 \mathrm{~cm}$ for $40 \mathrm{MHz}$ ) telescopic antenna elements on both the receiver and transmitter. Data were collected in continuous profile mode. The GPR system was mounted on two sleds, which were towed by snowmobile at an average speed of $10 \mathrm{~km} \mathrm{~h}^{-1}$. The antennas were positioned $30-40 \mathrm{~cm}$ above the surface on a wooden frame that rested on the plastic sleds (Fig. 2). Some noise might have been introduced by the operation on the rough glacier surface. The offset between antennas was limited by the standard cable length to $4 \mathrm{~m}$. The antennas were arranged parallel to each other and perpendicular to the profiling direction. In such a configuration, the larger coupling between antennas may be expected (Navarro and Eisen, 2009). Radar traces and GPS coordinates were recorded simultaneously. Conventional GPS with the nominal horizontal positioning accuracy of $\pm 5 \mathrm{~m}$ was used. Due to low air temperatures, battery lifetime was reduced by $\sim 50 \%$; however, we did not detect any overheating problems with the device, which are common when operating at elevations above $6000 \mathrm{~m}$.

After the radar data (radargrams) were collected, they were processed using Radan 7 software and exported to text format for further implementation in GIS. Data were obtained with the predefined parameters: continuous time survey mode, 32-bit data format, 256 samples per scan. Time/depth range varied between 2000 (GS) and 6000 (GP) ns. The processing steps included static correction to eliminate air wave reflections; bandpass filtering to improve the signal-to-noise ratio and to reduce high-frequency and low-frequency noise; background removal filter and a signal amplification filter (gain function) to account for signal loss with depth. Geometrical irregularities were corrected using Kirchhoff Migration method in RADAN 7 software. Profiles were digitized manually using the layer-picking mode to select the reflection arrival time from the ice/bed interface. The
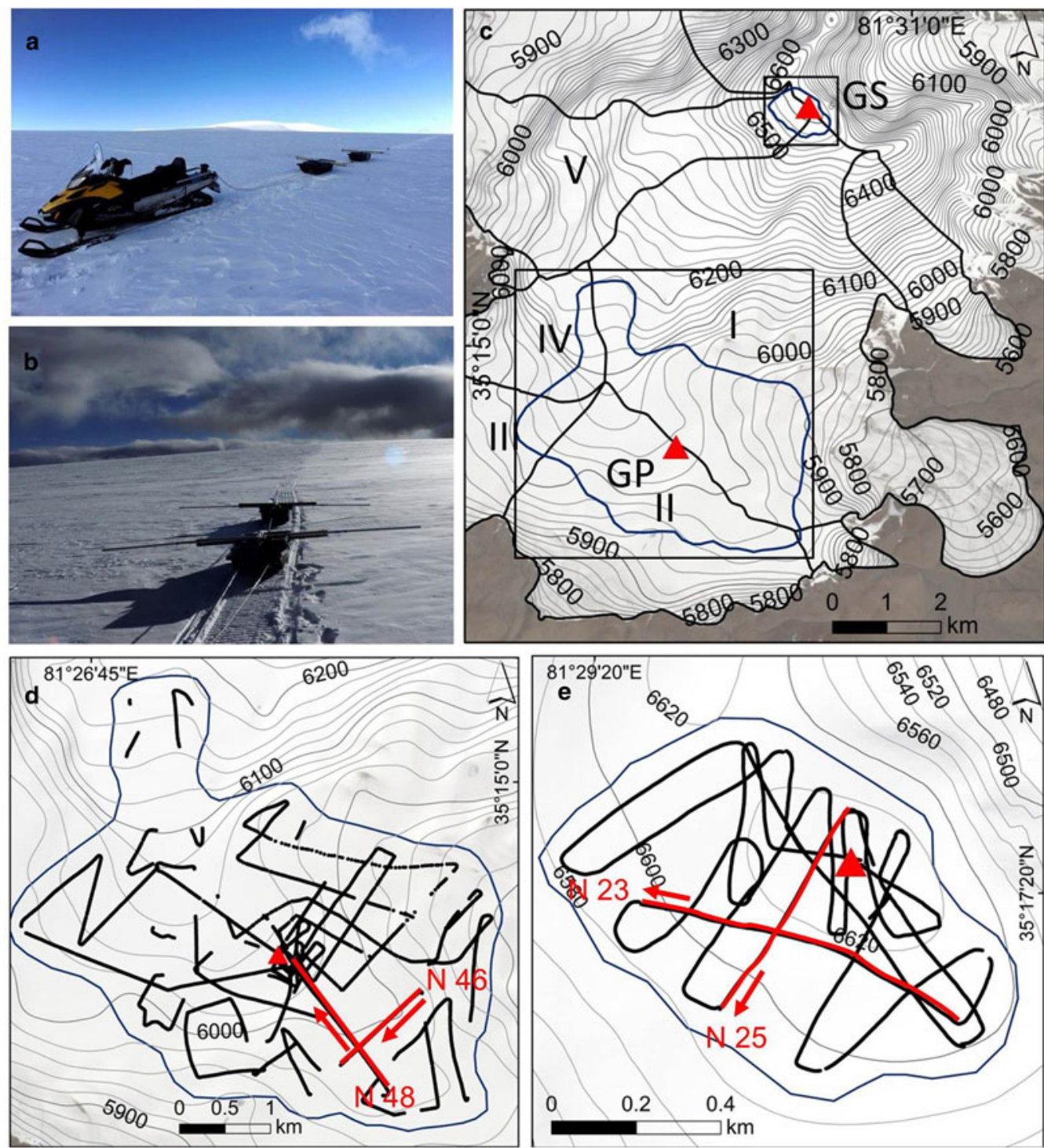

Fig. 2. (a, b) Photos showing measurement logistics on the GP. (c) Location of the GPR survey sites (blue lines), drilling sites (red triangles), surface topography and Guliya glacier basins (black outlines and numbers). GPR measurement profiles at the (d) GP and (e) GS sites. Background image is a Sentinel-2A image from 08 August 2017. Location and orientation of selected profiles discussed in the text are shown by red lines and red arrows, respectively. 
two-way travel time was then converted into ice thickness depending on the radio wave velocity (RWV).

\subsection{RWV calculation}

The theory of radio-wave propagation in glacier ice is described in detail elsewhere (e.g. Macheret, 2006; Navarro and Eisen, 2009). The best way to estimate the electromagnetic wave propagation velocity is to use common midpoint measurements. Unfortunately, these were not available; therefore, we used information about the underlying media provided by the ice core analysis.

The permittivity of snow, firn and ice to radio waves in the absence of liquid water depends mostly on density. Various empirical formulas and mixture models are used to estimate the mean permittivity of ice $(\varepsilon)$ (Looyenga, 1965; Robin, 1975). Another approach is to use the inversion of reflection amplitudes to compute the series of reflection coefficients that can be used to estimate the wave velocity in a depth interval within the glacier (Forte and others, 2014). Given the low temperatures throughout the glacier body, the absence of meltwater, and the very thin firn layer at the GP site, we used the constant propagation wave velocity of $0.168 \mathrm{~m} \mathrm{~ns}^{-1}$ for the dry ice (Dowdeswell and Evans, 2004).

At the GS drilling site, the presence of a thick firn cover prompted the use of the relationship determined by Kovacs and others (1995) to calculate RWV and to account for the density dependence of the electric permittivity of ice and firn:

$$
\varepsilon=(1+0.000845 \rho)^{2}
$$

where the density $\rho$ is in $\mathrm{kg} \mathrm{m}^{-3}$. The permittivity $\varepsilon$ was calculated for the upper $26 \mathrm{~m}$ at the GS drilling site using Eqn (1) and a third-order polynomial approximation of the density profile obtained from ice core analysis. The mean RWV $(u)$ was then computed as $u=c \varepsilon^{-0.5}$. Below $26 \mathrm{~m}$ depth, we used a constant velocity of $0.168 \mathrm{~m} \mathrm{~ns}^{-1}$ (Fig. 3). The assumption was made that density variations within the firn cover are similar throughout the GPR survey area.

\subsection{Ice thickness interpolation}

Ice thickness maps were created by interpolating ice thickness point data to a regular grid. Traditionally, the GPR data are interpolated by the means of probabilistic methods such as ordinary kriging. This method is not only used for data interpolation but also can be applied to predict interpolation uncertainty. Because we assume that the physical properties of the firn and ice do not vary with horizontal position and if only one semivariogram is used for all the observations, the ordinary kriging method then underestimates the interpolation error of the ice thickness data (Lapazaran and others, 2016a). Here we used an empirical Bayesian kriging (EBK) method for ice thickness interpolation and uncertainty assessment. This is a standard tool implemented in ArcGIS Geostatistical Analyst. Unlike classical kriging, the EBK accounts for the semivariogram model errors by automated subsetting of the observations and numerous repeated semivariogram model calculations. The resulting distribution of semivariograms is then used to predict values in unsampled locations and estimate prediction errors (Krivoruchko, 2012). The EBK method solves the problem of cross validation and underestimation of the interpolation error for the unevenly distributed GPR data and can be utilized with large data sets, which make it a useful tool for GPR measurements.

We used the following EBK parameters for interpolation of GP and GS ice thickness datasets: empirical transformation, K-Bessel semivariogram model, the subset size of 200 points for GP and 100 points for GS, an overlap factor of 3, and the number of simulations were set to 100 . For each site, the prediction and prediction errors maps were produced.

\subsection{Surface and basal topography}

In order to construct the basal topography map, the glacier surface elevation is required. The High Mountain Asia (HMA) 8-meter Digital Elevation Model (DEM) dataset generated from very-high-resolution imagery $(0.5 \mathrm{~m})$ from DigitalGlobe Inc. (available from the NASA National Snow and Ice Data Center Distributed Active Archive Center (https://nsidc.org/data/highmountainasia) was used as a source of topographic data for the GS site. A HMA DEM image acquired on 20 August 2015 was made available from the WORLDVIEW-1 imagery (Shean, 2017). For the GP site, gaps in HMA DEM were detected, which were filled by the Shuttle Radar Topography Mission X-band DEMs (http://eoweb.dlr.de:8080/free_SRTM_X-band_data. html) in 1-arc resolution, provided by the German Aerospace Centre (DLR). These DEMs were also used to estimate elevation changes. Co-registration and vertical biases were assessed using an approach based on the relationship of the resulting elevation differences with terrain slope and aspect over non-glacier areas (Nuth and Kääb, 2011). The HMA DEM was resampled to a $30 \mathrm{~m}$ resolution and elevation differences of more than $100 \mathrm{~m}$ were discarded. The comparison between two DEMs for 17513 pixels over non-glaciated areas resulted in std dev. of $3.62 \mathrm{~m}$. In order to construct the surface DEM for the GP site, the HMA DEM voids were filled with the SRTM-X DEM values which were corrected to account for an average elevation change over the Guliya glacier during the 2000-2015 period. The bed topography was calculated by subtracting the interpolated ice thickness values from the glacier surface DEM.

\section{ERROR ESTIMATION}

The accuracy of the ice thickness and bedrock topography was estimated following the approach and considerations published in a recent comprehensive review of errors involved in ice thickness estimations (Lapazaran and others, 2016a, b). The total error of gridded bedrock topography results from two major sources: errors in ice thickness DEM and surface DEM uncertainties. Ice thickness DEM accuracy depends on errors in GPR point measurements errors and interpolation errors. We analyzed each of these components separately for the GS and GP sites.

\subsection{Ice thickness measurement errors}

The total error of the GPR ice thickness estimation at a given point consists of two components: the error inherent in the measurements, and the horizontal positioning uncertainty (Lapazaran and others, 2016a). Measurement error is related to the chosen time-to-depth conversion $\left(\varepsilon_{\mathrm{c}}\right)$ and to the reflection picking accuracy or timing error $\left(\varepsilon_{\tau}\right)$. 


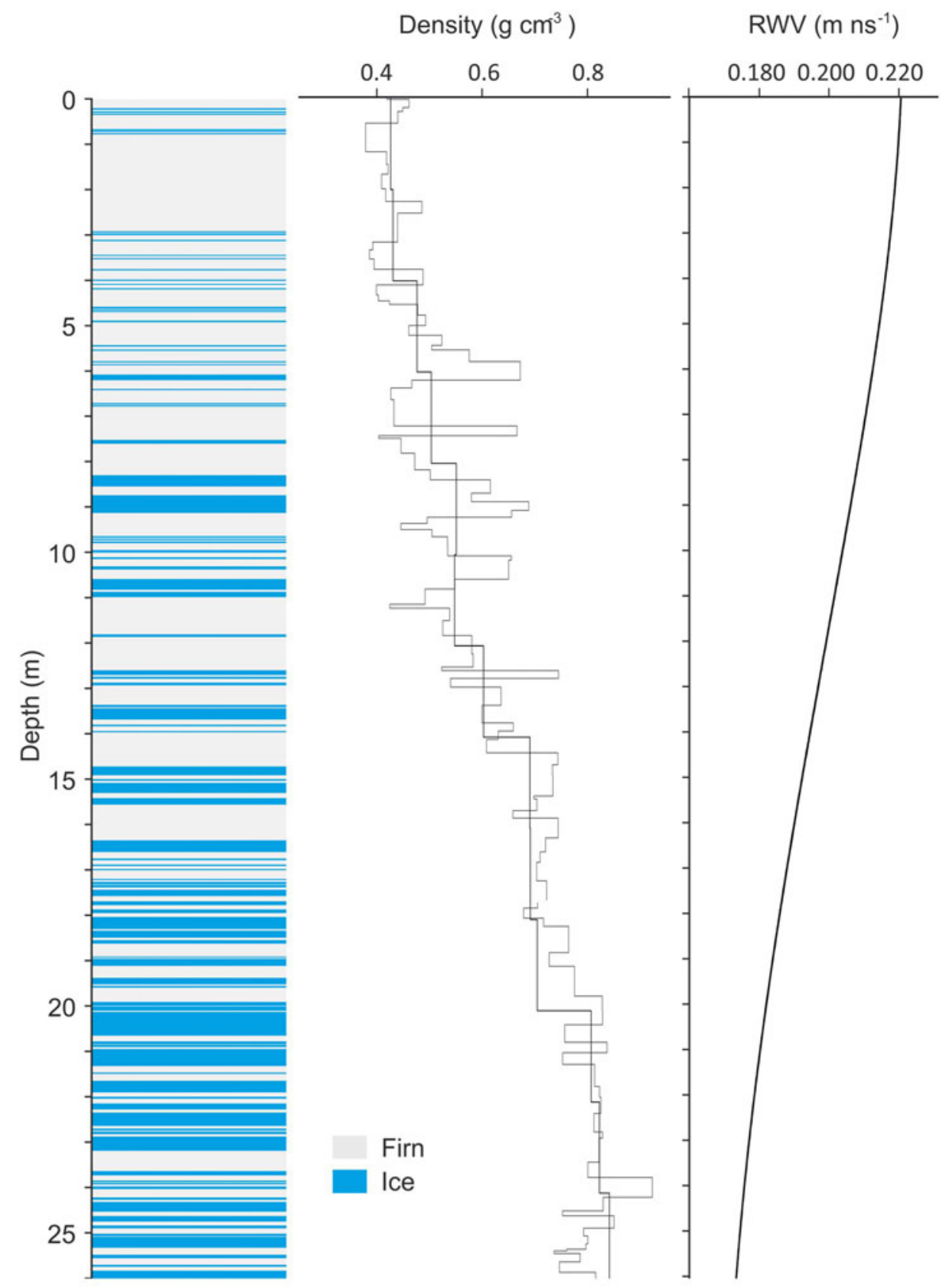

Fig. 3. Stratigraphy, bulk density, and $2 \mathrm{~m}$ average and calculated radio wave propagation velocity for the upper $26 \mathrm{~m}$ at the GS drilling site $(6650 \mathrm{~m})$ of Guliya glacier.

The differences between ice-thicknesses at the intersections of GPR profiles were analyzed to estimate the quality and consistency of the radar data obtained during the fieldwork. The statistics of the intersection differences illustrate the uncertainty in the radar data (e.g. Bamber and others, 2013; Martín-Español and others, 2013; Saintenoy and others, 2013). Since the measurements presented here were completed during one field campaign, the discrepancies at the intersections should be similar to the ice thickness errors (Navarro and others, 2014). However, it should be noted that while this tool provides insight into the presence of some inconsistencies, it does not allow accurate assessment of errors and serves only as an approximation. The std dev. of the intersection absolute differences for the GP site was $6.9 \mathrm{~m}$, with a mean value of $7.2 \mathrm{~m}$ or $3 \%$ of the mean measured ice thickness. For the GS site std dev. was $1.1 \mathrm{~m}$ and the mean difference was $2.3 \mathrm{~m}$ or $3.6 \%$.
To account for spatial variations of the RWV, a $2 \%$ uncertainty $\left(\varepsilon_{\mathrm{c}}\right)$ is assumed for both sites based on information of the underlying media properties from the ice cores analyses and borehole temperatures (Navarro and Eisen, 2009; Lapazaran and others, 2016a).

An additional error may be introduced to the RWV calculation at the GS site by the assumption of a uniform firn-ice transition depth throughout the survey area. Errors of total ice thickness estimation increase with the firn layer thickness (Babenko and Macheret, 1997; Macheret, 2006). The radargrams of the GS site show that the estimated maximum firn thickness was 35-40 m for the deepest parts. Since the difference in total ice thickness calculated by using the constant or variable firn-ice transition zone at the GS site was $\sim 1 \mathrm{~m}$, this error may be neglected.

Timing error $\varepsilon_{\tau}$ is related to the GPR resolution and includes errors in interpretation of the bed reflections. The 
latter can be evaluated from the central frequency as $\varepsilon_{\tau}=1 / f$, which is equivalent to half of the wavelength in terms of ice thickness. We used $20 \mathrm{MHz}$ antennas for the GP drilling site and $40 \mathrm{MHz}$ antennas for the GS site, which resulted in $\varepsilon_{\tau}$ values of $4.2 \mathrm{~m}$ and $2.1 \mathrm{~m}$, respectively, assuming the constant RWV of $0.168 \mathrm{~m} \mathrm{~ns}^{-1}$.

The additional uncertainty of the ice thickness estimation occurs from the horizontal-positioning error of each GPR trace. This error depends on the accuracy of the GPS positioning and traces positioning error due to GPR movement. To account for such uncertainties we used the approach described in detail in Lapazaran and others (2016a). The positioning error of stand-alone GPS was assumed to be $5 \mathrm{~m}$ and the positioning error due to GPR movement was estimated as $1.39 \mathrm{~m}$ since the time step between subsequent traces was set to $1 \mathrm{~s}$. This results in a total positioning error of $5 \mathrm{~m}$. To estimate the positioning-related ice thickness error, we calculated differences between measured ice thicknesses values located within a circle of $5 \mathrm{~m}$ radius from each other. The maximum discrepancies of 3.94 and $9.84 \mathrm{~m}$ were found at the GS and GP sites, respectively.

The resulting total GPR ice thickness measurement error was calculated for each data point. For the GS site, this produced values between 4.48 and $4.84 \mathrm{~m}$ with a mean of $4.61 \mathrm{~m}$ and std dev. of $0.09 \mathrm{~m}$. For the GP site, values of the total ice thickness measurement error varied between 10.82 and $13.02 \mathrm{~m}$ with a mean of $11.69 \mathrm{~m}$ and std dev. of $0.47 \mathrm{~m}$ (Table 1$)$

\subsection{Ice thickness interpolation errors}

Prediction of standard errors was made using an EBK (Krivoruchko, 2012). The cross-validation analysis showed that the EBK interpolation resulted in a root mean square error of $4.77 \mathrm{~m}$ for 5872 measurements at the GP site and $0.93 \mathrm{~m}$ for 1439 measurements the GS site. A prediction standard error map was calculated for both study areas. The average interpolation error for the GP area was $18.38 \mathrm{~m}$ with the std dev. of 11.75 and maximum of $73 \mathrm{~m}$ (Table 1). The errors propagate depending on the spatial density of the profiles, and the largest errors correspond to the areas with the least data coverage. The largest uncertainties were estimated in the north-west part of the GP site where the distance between the GPR profiles was several hundred meters. Therefore, at this location the uncertainty in ice thickness is about one-third of the ice thickness values. Another source of uncertainty is large variations in ice thicknesses over short distances. Such deviations were well described by the EBK method. Evenly distributed ice thickness measurement profiles at the summit provided more accurate interpolation, with an average error of $2.34 \mathrm{~m}$, std dev. of $1.9 \mathrm{~m}$, and maximum of $9.67 \mathrm{~m}$. Following suggestions in Lapazaran and others (2016a), errors in ice thickness at the data points were propagated to each grid by the means of kriging interpolation, which was applied to errors instead of ice thicknesses. The distribution of propagated errors was then combined with the interpolation errors as the root of their squared sum in each gridpoint providing the total ice-thickness error (Table 1; Figs 6b, 7b).

\subsection{Basal topography errors}

The total error in basal elevation at a given gridcell was calculated as a root mean square of the ice thickness grid and surface elevation DEM errors. The HMA-8 DEM acquired with the WorldView-1 along-track pairs have a horizontal/ vertical accuracy of $<5 \mathrm{~m}$ with the relative error of 1-2 $\mathrm{m}$ (Shean, 2017). SRTM X-band signal penetration can be considered negligible for the glaciers outside dry recrystallization zones (Gardelle and others, 2012). We consider std dev. of the DEMs difference for the non-glacier areas $(3.62 \mathrm{~m})$ as an uncertainty estimate for the DEM difference within the glacier.

\section{RESULTS AND DISCUSSION}

During the 2015 Guliya expedition, four ice cores were drilled to bedrock successfully. The longest core (309.72 m) was drilled on the GP using an electromechanical corer in a dry borehole. Here the firn/ice transition occurred in a surface layer of only $20-30 \mathrm{~cm}$ thickness. Ice temperatures were $-11.9,-6$ and $-2.1{ }^{\circ} \mathrm{C}$ at 15,200 and $309.72 \mathrm{~m}$, respectively. Three cores to bedrock $(50.72,51.38$ and $50.86 \mathrm{~m}$ ) were obtained from the GS within $5 \mathrm{~m}$ of each other. GS ice core stratigraphy in the upper $\sim 26 \mathrm{~m}$ consists of firn with numerous ice layers ranging from 1 to $33 \mathrm{~cm}$ thickness. Below the firn/ice transition, the cores are composed of glacier ice. The temperature profile in one of the boreholes shows a steady increase from $-17.2^{\circ} \mathrm{C}$ at $10 \mathrm{~m}$ depth to $-15^{\circ} \mathrm{C}$ at the bottom $(51 \mathrm{~m})$.

Examples of a typical radargrams for the GP site are shown in Figure 4. Radar data obtained with the $20 \mathrm{MHz}$ frequency at the GP site did not reveal any continuous internal reflections; however, the low frequency enabled ice/bed interface detection of the deeper $(>300 \mathrm{~m})$ parts. The basal reflections can be clearly seen at both profiles. We did not detect any point-like reflectors or areas of significant radar signal

Table 1. GPR ice thickness measurement errors (see the text for explanation)

\begin{tabular}{|c|c|c|c|c|c|c|c|c|c|c|c|c|c|}
\hline \multirow[b]{4}{*}{ Site } & & & \multicolumn{11}{|c|}{ Error analysis } \\
\hline & & & \multicolumn{5}{|c|}{ Measurement error } & & & & & & \\
\hline & \multicolumn{2}{|c|}{ Intersection } & \multirow{2}{*}{$\begin{array}{l}\varepsilon_{\tau} \\
\mathrm{m}\end{array}$} & \multirow{2}{*}{$\begin{array}{l}\varepsilon_{\mathrm{C}} \\
\%\end{array}$} & \multirow{2}{*}{$\begin{array}{l}\varepsilon_{\mathrm{H} x y} \\
\operatorname{Max} \\
\mathrm{m}\end{array}$} & \multicolumn{2}{|l|}{$\varepsilon_{\mathrm{gpr}}$} & \multicolumn{3}{|c|}{ Interpolation error } & \multicolumn{3}{|c|}{ Total ice-thickness DEM error } \\
\hline & $\begin{array}{l}\text { Mean } \\
\mathrm{m}\end{array}$ & $\begin{array}{l}\mathrm{SD} \\
\mathrm{m}\end{array}$ & & & & $\begin{array}{l}\text { Mean } \\
\mathrm{m}\end{array}$ & $\begin{array}{l}\mathrm{SD} \\
\mathrm{m}\end{array}$ & $\begin{array}{l}\text { Max } \\
\mathrm{m}\end{array}$ & $\begin{array}{l}\text { Mean } \\
\mathrm{m}\end{array}$ & $\begin{array}{l}\mathrm{SD} \\
\mathrm{m}\end{array}$ & $\begin{array}{l}\text { Max } \\
\mathrm{m}\end{array}$ & $\begin{array}{l}\text { Mean } \\
\mathrm{m}\end{array}$ & $\begin{array}{l}\text { SD } \\
\mathrm{m}\end{array}$ \\
\hline GP & 7.2 & 6.9 & 4.2 & 2 & 9.8 & 11.69 & 0.47 & 72.34 & 18.38 & 11.75 & 73.32 & 22.60 & 10.1 \\
\hline GS & 2.3 & 1.1 & 2.1 & 2 & 3.9 & 4.61 & 0.09 & 9.68 & 2.34 & 1.90 & 10.72 & 5.42 & 1.09 \\
\hline
\end{tabular}



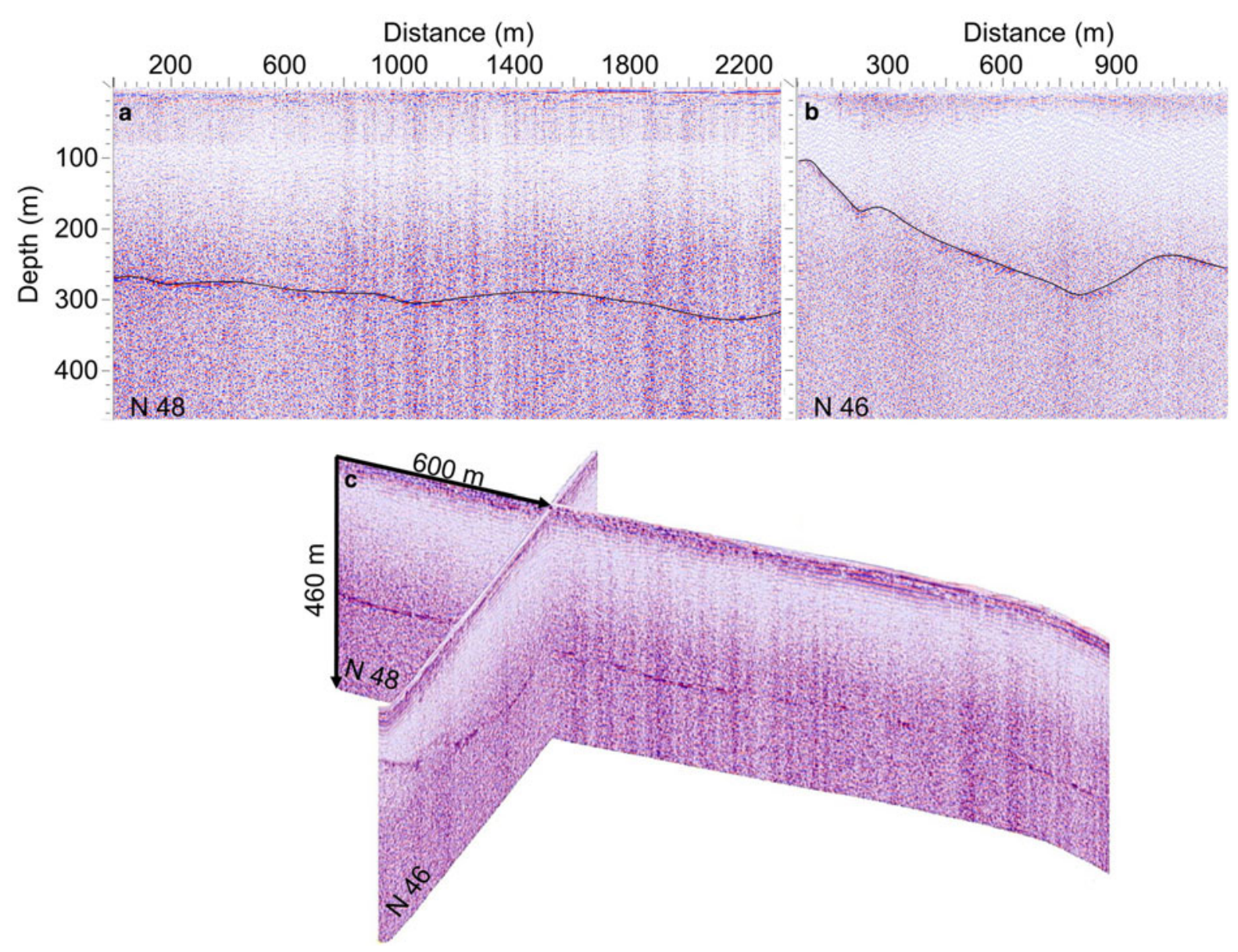

Fig. 4. Typical examples of initial GPR radargrams (not topographically corrected) profiles (a) N48 and (b) N46 on the GP. (c) 3D view of radargrams. Location and orientation of the profiles are shown in Fig. $2 \mathrm{~d}$.

scattering within the GP site which confirms the cold englacial thermal regime.

Figure 5 shows the measured ice thicknesses and basal topography around the GP site. The ice thickness measured $10-15 \mathrm{~m}$ from the GP drilling site was $306 \pm 12.33$ and $312 \pm 12.39 \mathrm{~m}$ for different profiles, which differed by $<4 \mathrm{~m}$ from the borehole depth $(309.73 \mathrm{~m})$, thus legitimizing the use of the constant RWV of $0.168 \mathrm{~m} \mathrm{~ns}^{-1}$ for the GP site. The maximum ice thickness of $371.12 \pm 13.02 \mathrm{~m}$ was measured at $1.3 \mathrm{~km}$ north-west of the GP drilling site. The mean measured ice thickness at the GP site was $228.76 \pm 11.69$ m (Fig. 5c, d).

Ice flow direction and glacier drainage basins were determined using a hydrological analysis of the surface topography in ArcGIS. Guliya ice cap can be separated into five major basins (see Fig. 2). The GP drilling site is located at the ice divide between two basins (I and II) where the ice stream from the higher elevations diverges to the east and the south. The surface topography reveals a gentle slope of $1.5-2^{\circ}$ along the ice divide. Basal topography maps based on the measured ice thicknesses reveal a complex bed (Fig. 5d). The longitudinal profile A-B in the NW to SE u-shaped subglacial valley in which the deep borehole is located is shown in Fig. 5e. The deepest depression, with an ice thickness of $370 \mathrm{~m}$, is located $1.5 \mathrm{~km}$ upstream and a 35-40 m high ridge lies between the depression and the drilling site. Another valley with much steeper slopes lies to the east of this depression, and here the ice flow is faster due to a sharp elevation drop, which was confirmed by the surface topography and presence of crevasses. Figure $5 f$ shows the cross section C-D from SW to NE over the GP drilling site. Over a distance of $0.5 \mathrm{~km}$, the ice depth changes from 320 to $150 \mathrm{~m}$, which illustrates the ruggedness of the bedrock. A relative rise of the surface by $\sim 15 \mathrm{~m}$ occurs $\sim 1 \mathrm{~km}$ from the borehole, despite the fact that this ice divide was positioned along the 100-140 m deep subglacial valley.

Sites suitable for drilling older ice cores are characterized by low ice accumulation rates, small flow velocity and high ice thickness and absence of ice flow disturbances. The surface topography and ice thickness distribution described above suggest low horizontal ice flux at the GP site. Subglacial relief is not reflected in surface topography; instead, the ice surface rise is observed at the ice divide, which is similar to the situation on polar ice caps. Deeper parts of the glacier were identified upstream from the GP site. But the steeper slopes together with the presence of the crevasses on the surface indicate faster ice flow at this location. This area is also an ice-divide between four ice drainage basins with a constant inflow of ice from the upper parts. The GP drilling site in contrast is located lower and the surface topography together with cold basal conditions suggest relatively slow ice flow in one direction following the subglacial valley. Overall the assessment of the surface and basal topography confirms suitability of the chosen ice core drilling site.

The internal reflections are shown on the $40 \mathrm{MHz}$ profiles obtained on the summit (Fig. 6). The GPR profiles from the drilling site reveal multiple continuous reflectors within the 

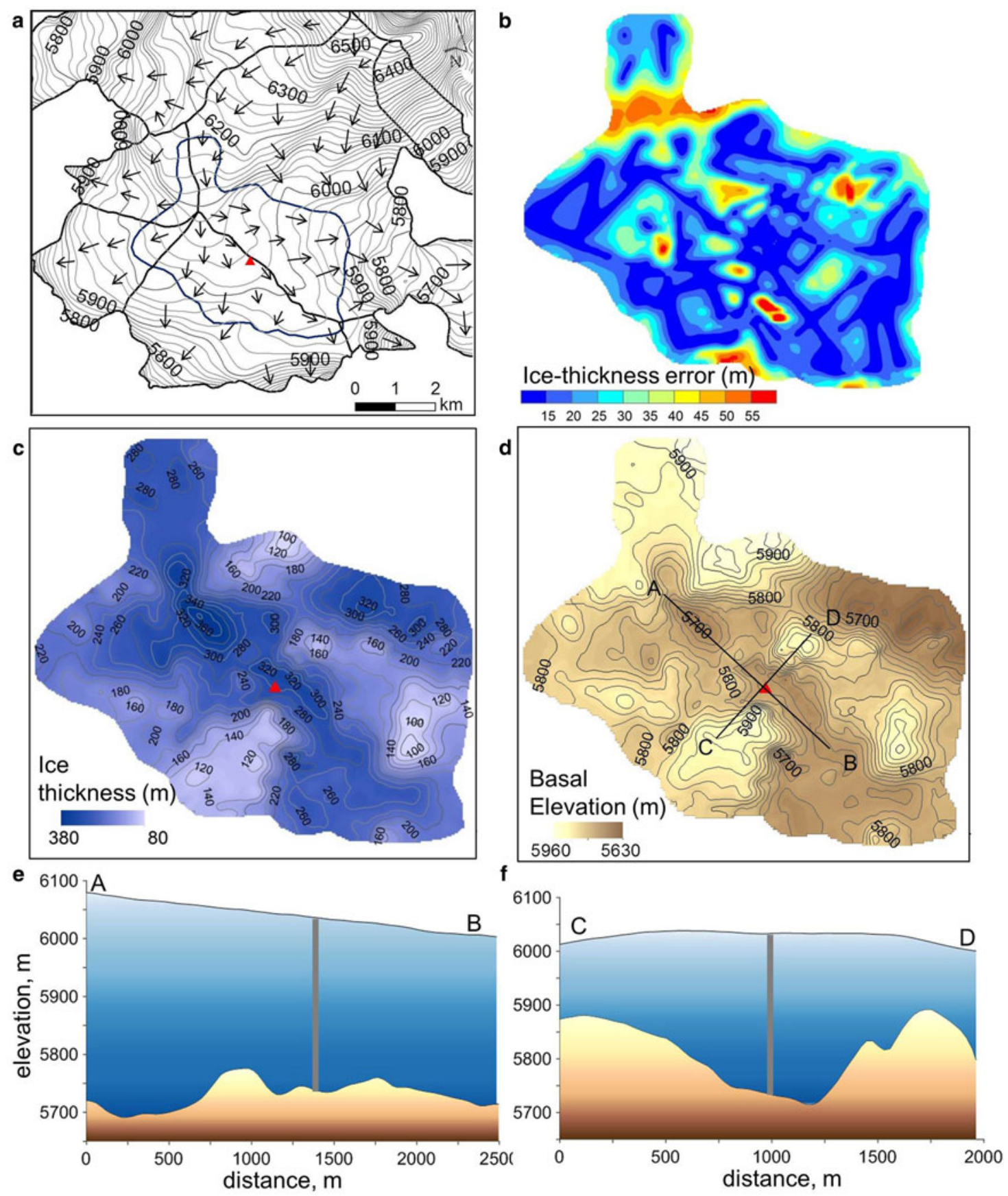

Fig. 5. (a) Surface topography, glacier ice drainage basins (black lines) and ice flow direction (arrows), GPR measurement GP site outline (blue line). (b) Total ice thickness error map for the GP site. (c) Ice thickness and (d) basal topography on the GP. Surface and basal topography at cross sections (e) A-B and ( $f$ ) C-D are shown.

upper 25-28 m (280-320 ns) (Fig. 6c). The lower part of the radargrams did not show any strong reflections from the internal layers, which is indicative of the complete firn-ice transition and a uniform ice density distribution. This conclusion is confirmed by the density measurements and stratigraphy analysis of the GS cores (Fig. 3). The high-resolution density profile shows large variations in the top $13-15 \mathrm{~m}$ in which numerous ice layers are present. Deeper in the profile, density becomes more uniform with an average value of $0.75 \mathrm{~g} \mathrm{~cm}^{-3}$, then gradually increases to the density of ice at the firn-ice transition zone. The numerous but relatively thin dust layers in the middle of the core did not influence the radar record, presumably due to the relatively low frequency of the GPR. We suggest that the observed continuous reflectors are isochrones composed of a number of variable-density layers. The internal reflectors generally follow the underlying basal topography and their shape primarily depends on accumulation rate distribution. Firn thickness reaches $35-40 \mathrm{~m} \mathrm{(380-430} \mathrm{ns)}$ at the SW slope of the summit area where ice thickness is almost $100 \mathrm{~m}$ (Fig. 6b).

Ice thicknesses and basal topography of the summit region around the drill sites are shown in Fig. 7. GPR profiles located 15-20 $\mathrm{m}$ away from the GS drilling site reveal ice/bed interface reflections at a depth of $48.5 \pm 4.53 \mathrm{~m}$ (Fig. 7), which agree well with the depths of three boreholes (50.72, 51.38 and $50.86 \mathrm{~m}$ ) drilled at the summit. Such a good agreement between GPR and borehole depths confirms our approach 


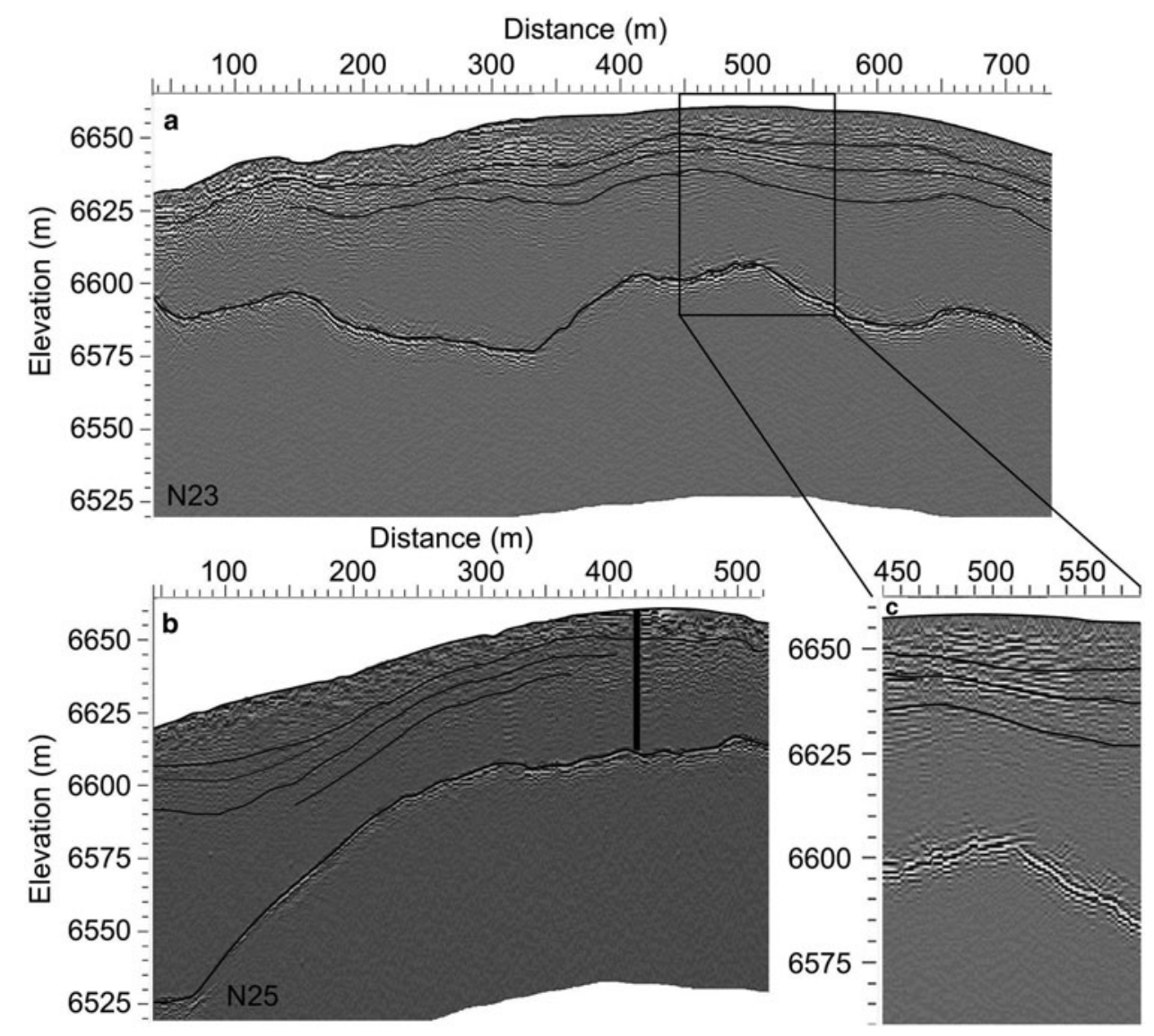

Fig. 6. Topographically corrected radargrams of GPR profiles (a) N23 and (b) N25 on the GS. The borehole location is shown as a thick black line. (c) The enlarged section of the N23 profile is shown. Selected internal reflections are illustrated in black. Location and orientation of profiles are shown in Fig. 2e.

to RWV calculations at the GS site. The average measured ice thickness for the GS site was $63 \pm 4.61 \mathrm{~m}$, with a maximum measurement of $97.64 \pm 4.84 \mathrm{~m}$. However, the use of $0.168 \mathrm{~m} \mathrm{~ns}^{-1}$ RWV for the same GPR data at the GS site results in larger uncertainty, leading to an ice thickness underestimation of $11 \%$. GRP results show uniform accumulation distribution and smooth, continuous, undisturbed internal glacier structure in the vicinity of the drilling site. The surface and basal topography confirms that the GS drilling site is located at the ice dome where the horizontal ice velocity is negligible.

These findings were compared with the results from the first GPR survey on the Guliya ice cap in May 1991 (Thompson and others, 1995). Point measurements revealed a similar u-shaped valley; however, the number of measurements was limited and it was impossible to make any reliable estimates of the actual ice thickness distribution. It has to be noted that the comparison is only qualitative and should not be used for verification as the accuracy of georeferencing in 1991 cannot be estimated. Nevertheless, the direct comparison between all the measured points available from the 1991 field notes and the published data in Thompson and others (1995) show a good agreement for the GP site. Measurements made in 1991 at seven points located within the area surveyed in 2015 on average show a 12 m lower ice thickness with a std dev. of $21 \mathrm{~m}$. The only available point measurements for the GS site showed an ice thickness of $103 \mathrm{~m}$, which is roughly twice as much as revealed by the drilling and GPR survey of 2015. This difference can be explained partly by the lack of georeferencing, but most likely is due to misinterpretation of the 1991 radar data. Only minor elevation and hence ice thickness changes are detected for the GS site between 2000 and 2015 and there is no reason to expect a significant ice thickness decrease between 1991 and 2000. Thus, it is possible that the multiple reflections (echoes) in the 1991 record were interpreted as real bedrock reflections, leading to an overestimation of the depth by a factor of two.

Results of the DEM differencing are presented in Fig. 8. The Alakesayi glacier to the north of Guliya was considered by Yasuda and Furuya (2015) to be a possible surging glacier, and the most noticeable feature of the DEM differencing results is the significant surface elevation change, which is due to a surge event (Fig. 8a, b). The WorldView-1 imagery of the Alakesayi glacier used for HMA-8 DEM was acquired in August 2015. Since 2000 the surface elevation had decreased by $40 \mathrm{~m}$ at the upper part of the glacier and increased by $60-80 \mathrm{~m}$ at the tongue, which indicated a fast glacier advance as registered by satellite imagery. The active phase of the surge event took place from 2015 to 2017 when the glacier advanced by $1.2 \mathrm{~km}$. However, a detailed investigation of this surge lies outside the scope of our study. In contrast, the Guliya ice cap does not reveal any signs of surging in the past, and is categorized as nonsurge type glacier (Yasuda and Furuya, 2015). Over the past 15 years since the SRTM mission, an overall rise of the Guliya glacier surface was observed (Fig. 8a, c). Surface elevation has increased by $8.64 \pm 3.62 \mathrm{~m}$ at the GS drilling site and by $4.93 \pm 3.62 \mathrm{~m}$ at the GP site. An average density of $0.47 \mathrm{~g} \mathrm{~cm}^{-3}$ was measured for the upper $9 \mathrm{~m}$ of firn in the 
a
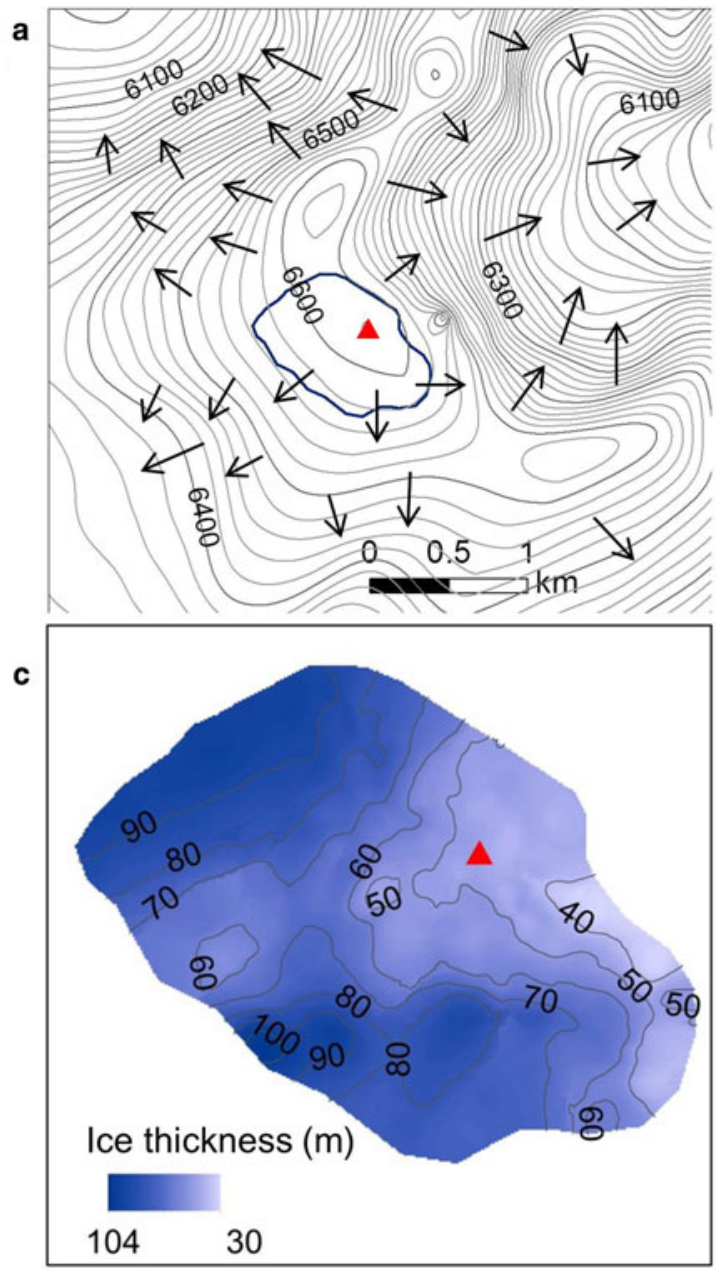

e

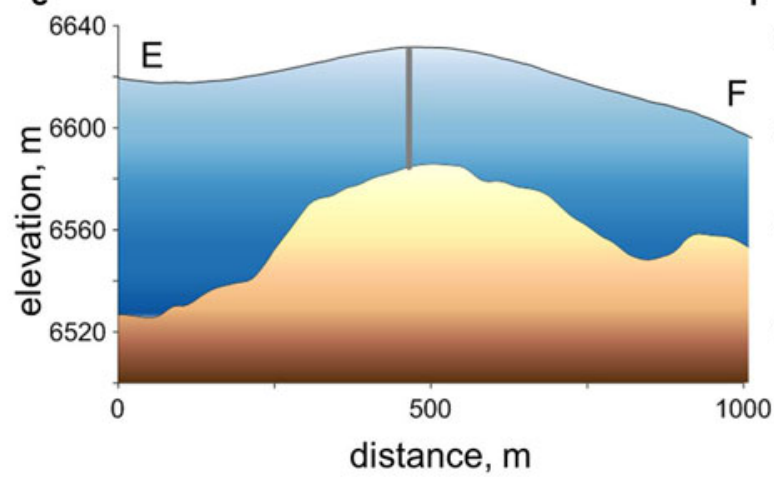

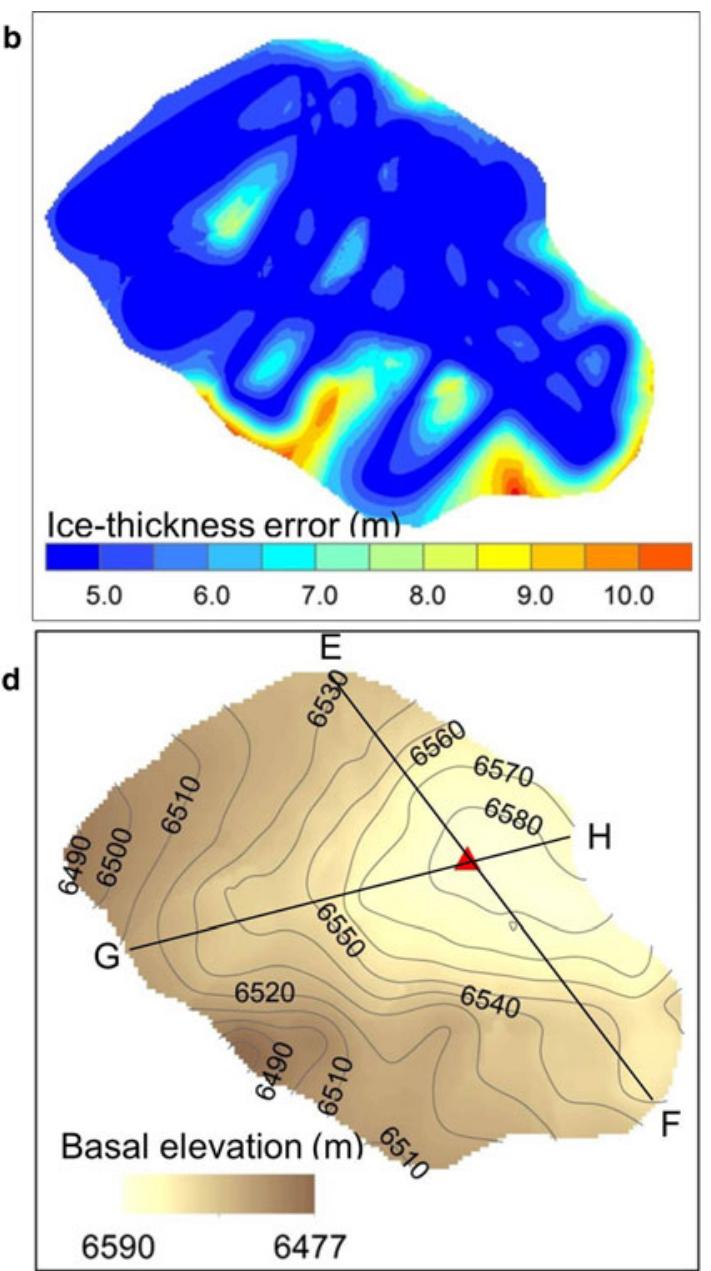

f

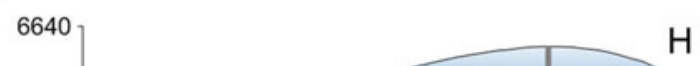

$\mathrm{H}$

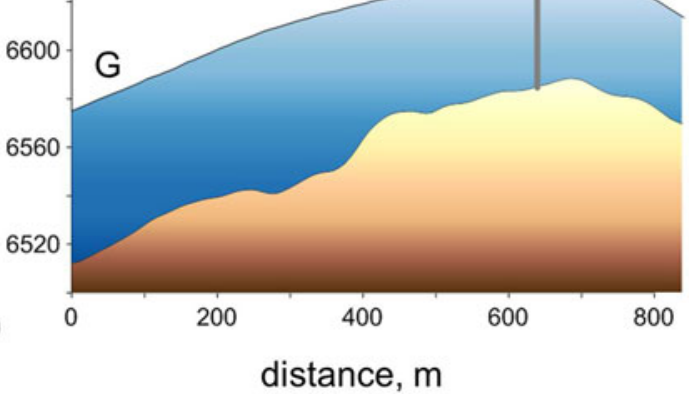

Fig. 7. (a) Surface topography, glacier ice drainage basins (black lines) and ice flow direction (arrows), GPR measurement GS site outline (blue line). (b) Total ice thickness error map for the GS site. (c) Ice thickness and (d) basal topography on the GS. Surface and basal topography at cross sections (c) E-F and (d) G-H are shown.

GS ice cores, while at the GP site average density is $0.85 \mathrm{~g}$ $\mathrm{cm}^{-3}$. This gives the specific annual mass balance of $0.270 \pm 0.11$ and $0.279 \pm 0.11 \mathrm{~m}$ w.e. $\mathrm{a}^{-1}$ at the GS and GP sites, respectively in 2000-2015. Essentially similar results within the range of uncertainty were obtained for the 1991-2015 period (GS: $0.106 \mathrm{~m}$ w.e. $\mathrm{a}^{-1}$; GP: $0.222 \mathrm{~m}$ w.e. $\mathrm{a}^{-1}$ ) by direct comparison of ice cores drilled in the early 1990s with the 2015 GP and GS cores (Thompson and others, 2018). The average surface increase over the entire Guliya glacier covered by the HMA-8 $\mathrm{m}$ DEM was $1.60 \pm 3.62 \mathrm{~m}$, or $0.09 \pm 0.11 \mathrm{mw}$.e. $\mathrm{a}^{-1}$ in $2000-2015$ period. Our results correspond well with recent studies of the glacier changes in West Kunlun glaciers and confirm the overall mass gain since the beginning of 21 st century. Based on a comparison of ICESat repeated tracks, Ke and others (2015) concluded that the surface of the Guliya ice cap was rising in the accumulation zone at an average rate of $0.3 \pm 0.1 \mathrm{~m} \mathrm{a}^{-1}$ during the 2003-08 period. Lin and others (2017) estimated a mass balance on Guliya of $0.230 \mathrm{~m}$ w.e. $\mathrm{a}^{-1}$ from 2000 to 2014 based on SRTM-X-band DEM and bistatic TerraSAR-X/TanDEM-X comparison. Slightly lower mass balance values obtained in our study may be explained by the HMA-8 m DEM data gaps which constitute approximately one-half of the glacier area. 


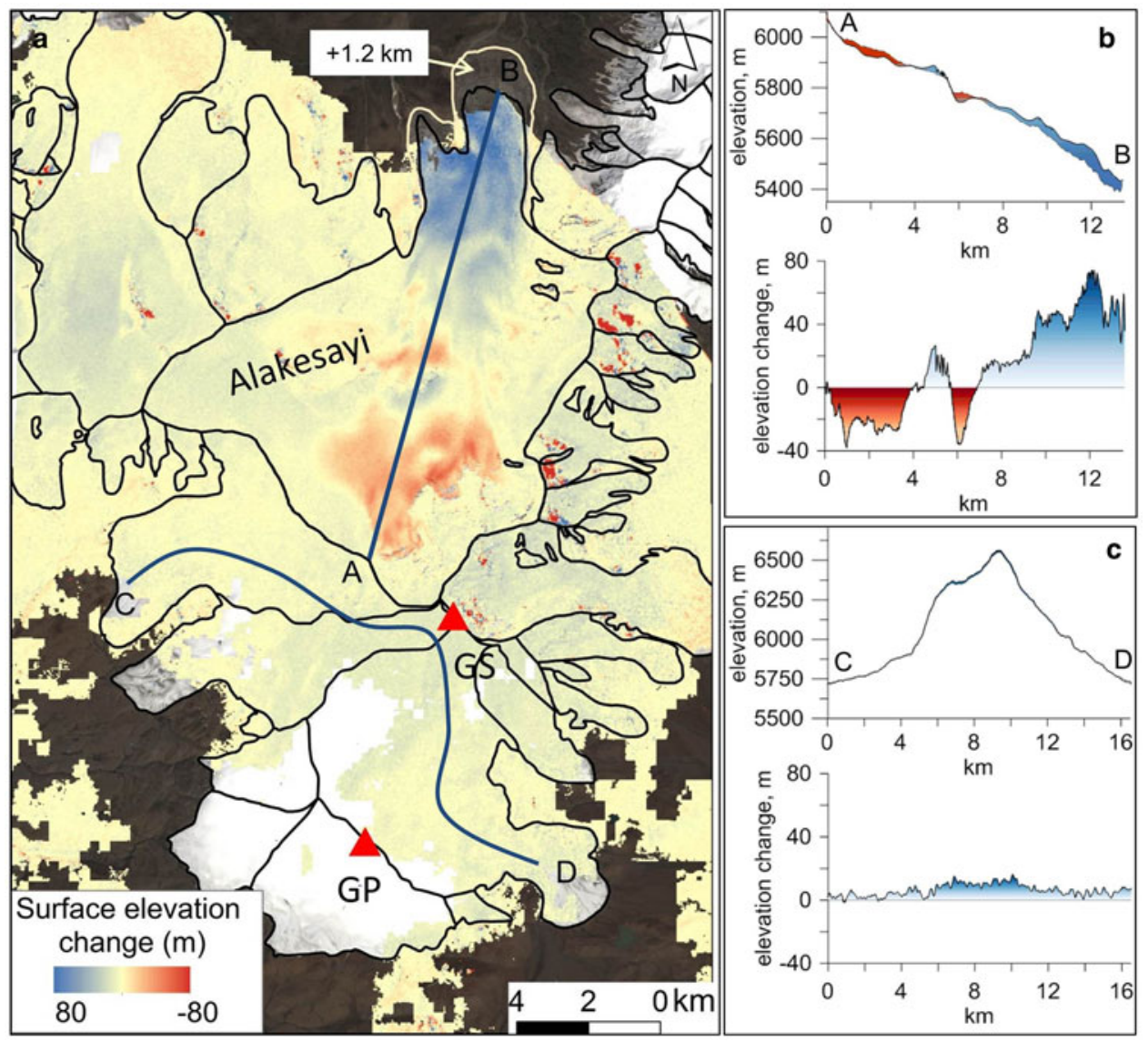

Fig. 8. (a) Surface elevation changes from 2000 to 2015 obtained as SRTM-X and HMA-8 DEM differencing. Area and length changes of the Alakesayi glacier in 2015-17 are shown. (b) and (c) Elevation changes for selected profiles at Alakesayi (A-B) and Guliya glacier (C-D). Areas not covered by the elevation change data represent gaps in HMA-8 DEM. Background image is a Sentinel-2A image from 08 August 2017.

\section{CONCLUSIONS}

We have presented a new and valuable ice thickness dataset collected in 2015 on the Guliya ice cap. GPR ice thickness data were compared with the borehole depths and ice core stratigraphy. The constant RWV of $0.168 \mathrm{~m} \mathrm{~ns}^{-1}$ provides the best match to borehole depth where firn is absent. The ice thickness measured near the GP drilling site differs by $<4 \mathrm{~m}$ from the borehole depth $(309.73 \mathrm{~m})$. For the GS where a firn layer is present, a calibration of the RWV using the density profile was used. Measured ice thickness near the GS site of $48.5 \pm 4.53 \mathrm{~m}$ agrees well with depths of the boreholes $(50.72,51.38$ and $50.86 \mathrm{~m})$.

The EBK used for the interpolation of the GPR data and interpolation uncertainty estimation is a useful tool for GPR measurements. It solves the problem of cross validation and underestimation of the interpolation error in an automated way by data subsetting and estimating semivariogram model errors. The major sources of interpolation uncertainty are the interpolation error between widely separated measurement profiles and the interpolation between profiles over areas of abrupt changes of ice thickness.

GPR measurements revealed complex basal topography in the vicinity of the GP drill site (Fig. 5). The average ice thickness on the plateau was $228.76 \pm 11.69 \mathrm{~m}$, with a maximum thickness of $371.12 \pm 13.02 \mathrm{~m}$. Radar data obtained using the $20 \mathrm{MHz}$ frequency antennas on the GP did not reveal any continuous internal reflections; however, the low frequency enabled ice/bed interface detection in the deeper parts (Fig. 4). Surface topography and ice thickness distribution suggest low horizontal ice flux on the GP.
The average measured ice thickness on the GS site was $63 \pm 4.61 \mathrm{~m}$, and the maximum was $97.64 \pm 4.84 \mathrm{~m}$ (Fig. 7). Uninterrupted internal reflections were registered at the GS drilling site by the $40 \mathrm{MHz}$ frequency GPR (Fig. 6). They were interpreted as isochrone layers that resulted from firn density variations.

The Guliya ice cap gained mass from 2000 to 2015 . The surface elevation increased by $8.64 \pm 3.62 \mathrm{~m}(0.270 \pm 0.11 \mathrm{~m}$ w.e. $\left.\mathrm{a}^{-1}\right)$ at the GS drilling site and by $4.93 \pm 3.62 \mathrm{~m}(0.279$ $\pm 0.11 \mathrm{~m} \mathrm{w.e.}^{-1}$ ) at the GP site (Fig. 8). The average surface elevation increase over Guliya that was covered by the HMA-8 $\mathrm{m}$ DEM was $1.60 \pm 3.62 \mathrm{~m}$ or $0.09 \pm 0.11 \mathrm{~m}$ w.e. $\mathrm{a}^{-1}$.

Our data complement the world's ice thickness dataset and can be used for further improvements of ice thickness models for ice caps and are archived at https://www.ncdc. noaa.gov/paleo/study/25130.

\section{ACKNOWLEDGEMENTS}

This research was accomplished as part of collaborative expedition between The Ohio State University's Byrd Polar and Climate Research Center (BPCRC) and the Institute of Tibetan Plateau Research (ITP) of the Chinese Academy of Sciences funded by the National Science foundation Paleoclimate Program award \#1502919 and the Chinese Academy of Sciences, respectively. We thank all the field and laboratory team members from the Institute of Tibetan Plateau Research led by Prof. Tandong Yao, and from the Ohio State University's Byrd Polar and Climate Research Center for their invaluable contribution in supporting the 
2015 Guliya field project. A special thanks to Dr Emilie Beaudon (BPCRC) for making the density and stratigraphy measurements shown in Fig. 3. This is Byrd Polar and Climate Research Center contribution number 1566.

\section{REFERENCES}

Babenko AN and Macheret YY (1997) The influence of the firn layer on the accuracy measurements of polar glaciers parameters by common midpoint method. Data Glaciol. Stud., 83, 183-190

Bamber JL and 10 others (2013) A new bed elevation dataset for Greenland. Cryosphere, 7(2), 499-510 (doi: 10.5194/tc-7-4992013)

Baojuan $\mathrm{H}$ and 5 others (2015) Glacier volume estimation from icethickness data, applied to the Muz Taw glacier, Sawir Mountains, China. Environ. Earth Sci., 74(3), 1861-1870 (doi: 10.1007/ s12665-015-4435-2)

Bohleber P and 10 others (2017) Ground-penetrating radar reveals ice thickness and undisturbed englacial layers at Kilimanjaro's Northern Ice Field. Cryosphere, 11(1), 469-482 (doi: 10.5194/ tc-11-469-2017)

Bolch T and 11 others (2012) The state and fate of Himalayan glaciers. Science (80-.), 336(6079), 310-314 (doi: 10.1126/ science.1215828)

Dowdeswell JA and Evans S (2004) Investigations of the form and flow of ice sheets and glaciers using radio-echo sounding. Reports Prog. Phys., 67(10), 1821-1861 (doi:10.1088/00344885/67/10/R03)

Eisen O, Nixdorf U, Keck L and Wagenbach D (2003) Alpine ice cores and ground penetrating radar: combined investigations for glaciological and climatic interpretations of a cold Alpine ice body. Tellus, Ser. B Chem. Phys. Meteorol., 55(5), 10071017 (doi: 10.1034/j.1600-0889.2003.00080.x)

Farinotti D and 7 others (2015) Substantial glacier mass loss in the Tien Shan over the past 50 years. Nat. Geosci., 8(9), 716-722 (doi: 10.1038/ngeo2513)

Farinotti D and 36 others (2017) How accurate are estimates of glacier ice thickness? Results from ITMIX, the Ice Thickness Models Intercomparison eXperiment. Cryosphere, 11(2), 949970 (doi: 10.5194/tc-11-949-2017)

Forte E, Dossi M, Pipan M and Colucci RR (2014) Velocity analysis from common offset GPR data inversion: theory and application to synthetic and real data. Geophys. J. Int., 197(3), 1471-1483 (doi: 10.1093/gji/ggu103)

Gabbi J, Farinotti D, Bauder A and Maurer H (2012) Ice volume distribution and implications on runoff projections in a glacierized catchment. Hydrol. Earth Syst. Sci., 16(12), 4543-4556 (doi: 10.5194/hess-16-4543-2012)

Gardelle J, Berthier E and Arnaud Y (2012) Impact of resolution and radar penetration on glacier elevation changes computed from DEM differencing. J. Glaciol., 58(208), 419-422 (doi: 10.3189/ 2012JoG11J175)

Gärtner-Roer I and 5 others (2014) A database of worldwide glacier thickness observations. Glob. Planet. Change, 122, 330-344 (doi: 10.1016/j.gloplacha.2014.09.003)

Gärtner-Roer I and 18 others (2016) WGMS (2016): Glacier Thickness Database 2.0. World Glacier Monitoring Service (doi: 10.5904/wgms-glathida-2016-07)

Ke L, Ding X and Song C (2015) Heterogeneous changes of glaciers over the western Kunlun Mountains based on ICESat and Landsat-8 derived glacier inventory. Remote Sens. Environ., 168, 13-23 (doi: 10.1016/j.rse.2015.06.019)

Kehrl LM, Hawley RL, Osterberg EC, Winski DA and Lee AP (2014) Volume loss from lower Peyto Glacier, Alberta, Canada, between 1966 and 2010. J. Glaciol., 60(219), 51-56 (doi: 10.3189/ 2014JoG13J039)

Konrad H, Bohleber P, Wagenbach D, Vincent C and Eisen O (2013) Determining the age distribution of Colle Gnifetti, Monte Rosa, Swiss Alps, by combining ice cores, ground-penetrating radar and a simple flow model. J. Glaciol., 59(213), 179-189 (doi: 10.3189/2013JoG12J072)

Kovacs A, Gow AJ and Morey RM (1995) The in-situ dielectric constant of polar firn revisited. Cold Reg. Sci. Technol., 23(3) 245-256 (doi: 10.1016/0165-232X(94)00016-Q)

Krivoruchko K (2012) Empirical Bayesian Kriging implemented in ArcGIS Geostatistical Analyst. ArcUser Fall

Lapazaran JJ, Otero J, Martin-Español A and Navarro FJ (2016a) On the errors involved in ice-thickness estimates I: ground-penetrating radar measurement errors. J. Glaciol., 62(236), 1008-1020 (doi: 10.1017/jog.2016.93)

Lapazaran JJ, Otero J, Martín-Español A and Navarro FJ (2016b) On the errors involved in ice-thickness estimates II: errors in digital elevation models of ice thickness. J. Glaciol., 62(236), 10211029 (doi: 10.1017/jog.2016.94)

Lin H, Li G, Cuo L, Hooper A and Ye Q (2017) A decreasing glacier mass balance gradient from the edge of the Upper Tarim Basin to the Karakoram during 2000-2014. Sci. Rep., 7(1), 1-9 (doi: 10.1038/s41598-017-07133-8)

Looyenga H (1965) Dielectric constant of heterogeneous mixtures. Physica, 21, 401-406

Macheret YY (2006) Radio-echo sounding of glaciers. Scientific World, Moscow

Martín-Español A and 7 others (2013) Radio-echo sounding and ice volume estimates of western Nordenskiöld Land glaciers, Svalbard. Ann. Glaciol., 54(64), 211-217 (doi: 10.3189/2013 AoG64A109)

Mikhalenko $V$ and 13 others (2015) Investigation of a deep ice core from the Elbrus western plateau, the Caucasus, Russia. Cryosphere, 9(6), 2253-2270 (doi: 10.5194/tc-9-2253-2015)

Navarro F and Eisen O (2009) Ground-penetrating radar in glaciological applications. In Pellikka P and Rees WG eds. Remote Sensing Glaciers., 195-229 (doi: 10.1201/b10155-12)

Navarro FJ and 6 others (2014) Ice volume estimates from groundpenetrating radar surveys, Wedel Jarlsberg land glaciers, Svalbard. Arctic, Antarct. Alp. Res., 46(2), 394-406 (doi: 10.1657/1938-4246-46.2.394)

Neckel N, Kropáček J, Bolch T and Hochschild V (2014) Glacier mass changes on the Tibetan Plateau 2003-2009 derived from ICESat laser altimetry measurements. Environ. Res. Lett., 9(1), 14009 (doi: 10.1088/1748-9326/9/1/014009)

Nuth C and Kääb (2011) Co-registration and bias corrections of satellite elevation data sets for quantifying glacier thickness change. Cryosphere, 5(1), 271-290 (doi: 10.5194/tc-5-271-2011)

Pälli A and 6 others (2002) Spatial and temporal variability of snow accumulation using ground-penetrating radar and ice cores on a Svalbard glacier. J. Glaciol., 48(162), 417-424 (doi: 10.3189/ 172756502781831205)

RGI Consortium (2017) Randolph Glacier Inventory - A Dataset of Global Glacier Outlines: Version 6.0: Technical Report (https:// doi.org/10.7265/N5-RGI-60)

Robin GDQ (1975) Velocity of radio waves in ice by means of a bore-hole interferometric technique. J. Glaciol., 15(73), 151-159 (doi: 10.3189/S0022143000034341)

Saintenoy A and 7 others (2013) Deriving ice thickness, glacier volume and bedrock morphology of Austre Lovénbreen (Svalbard) using GPR. Near Surf. Geophys., 11(2), 253-261 (doi: 10.3997/1873-0604.2012040)

Shean D (2017) High Mountain Asia 8-meter DEMs Derived from Along-track Optical Imagery, Version 1 (https://doi.org/10.5067/ GSACB044M4PK)

Shean DE and Marchant DR (2010) Seismic and GPR surveys of Mullins Glacier, mcmurdo dry valleys, Antarctica: ice thickness, internal structure and implications for surface ridge formation. J. Glaciol., 56(195), 48-64 (doi: 10.3189/002214310791190901)

Singh SK, Rathore BP, Bahuguna IM, Ramnathan AL and Karthic A (2012) Estimation of glacier ice thickness using Ground Penetrating Radar in the Himalayan region. Curr. Sci., 103(1), 68-73 http://www.scopus.com/inward/record.url?eid=2-s2.084866437923\&partnerlD=40\&md5=2d07a2c0c6a27685402cd $638 \mathrm{e} 8 \mathrm{e} 4 \mathrm{bfa} 3$ 
Sold L, Huss M, Eichler A, Schwikowski M and Hoelzle M (2015) Unlocking annual firn layer water equivalents from ground-penetrating radar data on an Alpine glacier. Cryosphere, 9(3), 10751087 (doi: 10.5194/tc-9-1075-2015)

Sorg A, Bolch T, Stoffel M, Solomina O and Beniston M (2012) Climate change impacts on glaciers and runoff in Tien Shan (Central Asia). Nat. Clim. Chang., 2(10), 725-731 (doi: 10.1038/nclimate1592)

Thompson LG and 6 others (1995) A 1000 year climate ice-core record from the Guliya ice cap, China: its relationship to global climate variability. Ann. Glaciol., 21, 175-181 (doi:10.3189/ S0260305500015780)

Thompson LG and 9 others (1997) Tropical climate instability: the last glacial cycle from a Qinghai-Tibetan ice core. Science (80-.), 276(5320), 1821 LP-1825 http://science.sciencemag.org/content/ 276/5320/1821.abstract

Thompson LG and 12 others (2018) Ice core records of climate variability on the Third Pole with emphasis on the Guliya ice cap, western Kunlun Mountains. Quat. Sci. Rev., 188, 1-14 (doi: 10.1016/j.quascirev.2018.03.003)

Tian L and 5 others (2014) Direct measurement of glacier thinning on the Southern Tibetan Plateau (Gurenhekou, Kangwure and Naimona'Nyi glaciers). J. Glaciol., 60(223), 879-888 (doi: 10.3189/2014JoG14J022)

Vincent C, Descloitres M, Gilbert A and Legchenko A (2012) Detection of a subglacial lake in Glacier de Tête Rousse (Mont Blanc area, France). J. Glaciol. 58(211), 866-878 (doi: 10.3189/ 2012JoG11J179)

Wang P and 5 others (2014) Ice thickness, volume and subglacial topography of Urumqi Glacier No. 1, Tianshan mountains, central Asia, by ground penetrating radar survey. J. Earth Syst. Sci., 123(3), 581-591 (doi: 10.1007/s12040-014-0421-4)

Yao T, Jiao K, Zhang X, Yang Z and Thompson LG (1992) Glaciologic studies on Guliya Ice Cap. J. Glaciol. Geocryol., 14 (3), 233-241 http://210.72.80.159/jweb_bcdt/EN/

Yao T and 14 others (2012a) Third Pole Environment (TPE). Environ. Dev., 3, 52-64 (doi: 10.1016/j.envdev.2012.04.002)

Yao T and 14 others (2012b) Different glacier status with atmospheric circulations in Tibetan Plateau and surroundings. Nat. Clim. Chang., 2(9), 663-667 (doi: 10.1038/ nclimate1580))

Yasuda T and Furuya M (2015) Dynamics of surge-type glaciers in West Kunlun Shan, Northwestern Tibet. J. Geophys. Res. F Earth Surf., 120(11), 2393-2405 (doi: 10.1002/2015JF003511)

Ye Q and 5 others (2017) Glacier changes on the Tibetan Plateau derived from Landsat imagery: mid-1970s-2000-13. J. Glaciol., 63(238), 273-287 (doi: 10.1017/jog.2016.137)

Yi S and Sun W (2014) Evaluation of glacier changes in high-mountain Asia based on 10 year GRACE RL05 models. J. Geophys. Res. Solid Earth, 119(3), 2504-2517 (doi: 10.1002/2013 JB010860)

Zekollari H, Fürst JJ and Huybrechts P (2014) Modelling the evolution of Vadret da Morteratsch, Switzerland, since the Little Ice Age and into the future. J. Glaciol. 60(224), 1155-1168 (doi: 10.3189/2014JoG14J053)

Zhu D, Tian L, Wang J and Cui J (2014) The Qiangtang Glacier No. 1 in the middle of the Tibetan Plateau: depth sounded by using GPR and volume estimated. J. Glaciol. Geocryol., 36(2), 278-285 